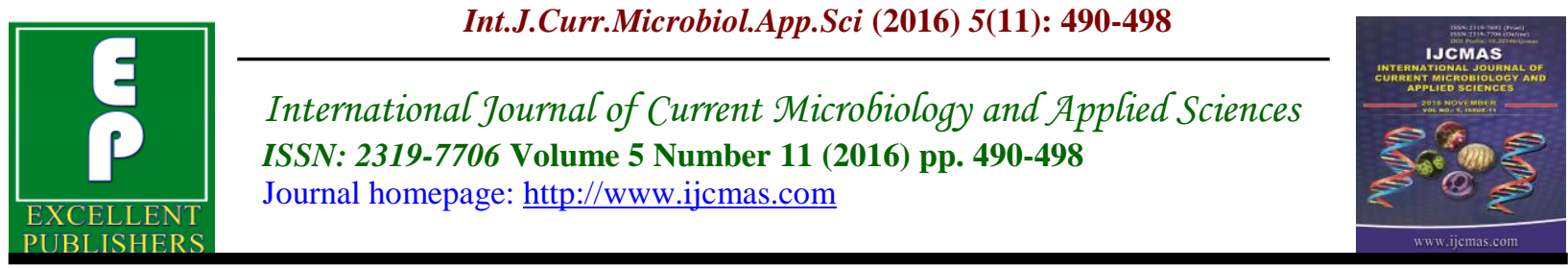

Original Research Article

http://dx.doi.org/10.20546/ijcmas.2016.511.057

\title{
Isolation and Screening of Probiotic Potential Lactic Acid Bacteria from Local Dairy Products
}

\author{
S.A. Patel and S.C. Parikh* \\ P.G. Centre in Microbiology, Smt. S. M. Panchal Science College, Talod, Gujarat, India \\ *Corresponding author
}

\section{A B S T R A C T}

Keywords

Lactic acid

bacteria,

Probiotic,

Curd,

Milk.

Article Info

Accepted:

23 October 2016

Available Online:

10 November 2016
The aim of this study was to isolate and identify Lactic acid bacteria having probiotics property from Curd and buttermilk. There were 77 different bacteria isolated from curd and buttermilk. Among 77 isolates, potential bacterial isolates SS-1, SS-2 and SS-3 were further selected to evaluate their probiotic properties. The selected bacterial isolates were found to resistant at low $\mathrm{pH} 3$ and with $0.5 \%$ bile salts concentrations. The isolates SS-1, SS-2 and SS-3 showed significant antibacterial activity against E. coli (MTCC1610), S. aureus (MTCC-1430), B. subtilis (MTCC-441), and P. vulgaris (MTCC-1771). Present study indicated that local dairy products can be used as a good source for isolation and screening of novel potential probiotic isolates.

\section{Introduction}

Isolation and screening of microorganisms from naturally occurring processes have always been the most powerful means for obtaining useful cultures for scientific and commercial purposes. This is certainly true for lactic acid bacteria (LAB), which play major attention for their widespread use in the production of fermented foods (Farnworth, 2005) which are characterized by hygienic safety, better organoleptic properties and perhaps the probiotic qualities (Savadogo et al., 2006). LAB are used as starter culture in fermentation and some of them are also natural component of intestinal micro flora (Fuller, 1992), (Holzapfel et al., 2001). Lactobacilli are one of the most important genera of LAB
(Coeuret et al., 2003) and have tremendous industrial application (Stiles, 1996). The art of lactic acid fermentation is one of the oldest technologies that preserve the milk in a wide diversity of flavor, aromas and texture (Minamiyama et al., 2003). Various strains of Lactobacilli are used as healthpromoting probiotic ingredients since they have several therapeutic functions (Oberg et al., 1998) including antibiotic resistance (Curragh and Collins, 1992), bile tolerance (Walker and Gilliland, 1983) and gastric juice tolerance (Kilara, 1982). Lactobacilli comprise a large and diverse group of Gram positive, nonspore forming, catalase negative, and rod shaped bacteria able to produce lactic acid as the main end product 
of the fermentation of carbohydrates (Pelinescu et al., 2009).

Different Lactobacillus species are nonpathogenic and do not produce toxic substances hence designed as "Generally Regarded as Safe" (GRAS). In recent years much attention is being given to isolation of Lactobacilli from different sources which are also used as bio preservatives traditional fermented milk product and is a very popular menu at the end of the meal in India subcontinent. The role of fermented milk in human diet was known from Vedic times. About $9 \%$ of the total milk is converted into fermented dairy product in India. Curd (Dahi), Buttermilk (chhass), sweetened yoghurt (lassi) are some of the traditionally fermented dairy products being used in every household of the Indian subcontinent. Among them Curd stands next to whole milk especially during summer. It is very easy to digest and enriched with vitamins, amino acids, pre digested protein and bioactive peptides, etc. (Campbell-Platt G., 1994).

In the Ayurveda Curd has been recommended for treatment of diarrhea and other acute/chronic gastrointestinal disorders from time immemorial. Lactic acid bacteria are the dominant microorganism found in Curd (Rashid et al., 2007) Curd is manufactured from milk by traditional method using $\mathrm{LAB}$ as indigenous starter culture. However, very little information is available on the characteristics of Lactobacillus microflora present in locally available dairy products. In these products, the species combination of $\mathrm{LAB}$ is more varying and inconsistent as compared to those of the trade products. The dairy industries require well-defined single strain and multiple strain starter cultures to obtain dairy products of high and constant quality. Therefore, a continuous need exists for the isolation of new strains with superior natural qualities. To provide health benefits by Lactobacilli present in dairy products, they require their relevant characterization and identification. The present study has been carried out with an objective to screen potential probiotic important novel species of Lactobacilli from fermented milk products from local dairy products vendors at Himatnagar, Dist. Sabarkantha, Gujarat and to study probiotic properties of isolated LAB.

\section{Materials and Methods}

\section{Collection of Samples}

Curd and buttermilk samples were collected from Local dairy products vendors of Himatnagar, Dist. Sabarkantha, Gujarat. Immediately after collection, the samples were stored aseptically in low temperature $\left(4^{\circ} \mathrm{C}\right)$ refrigerator to protect from contamination and spoilage.

\section{Isolation of Lactic Acid Bacteria}

Approximately $10.0 \mathrm{~g}$ of each Curd or buttermilk samples were mixed with $90 \mathrm{ml}$ of sterile peptone water $(0.1 \% \mathrm{w} / \mathrm{v}$ in distilled water), homogenized gently, diluted appropriately and spread plated aseptically on de Mann Rogosa Sharpe (MRS) agar media. Duplicate plates were incubated at $37^{\circ} \mathrm{C}$ for 48 hours in aerobic condition. Plates having less than 30 colonies were selected. Colonies differ in morphology, pigmentation, shape, and size were sub cultured to obtain purity in MRS broth. Purification of the isolates was confirmed by using various biochemical tests as described by Harrigan, 1998; Aneja, 2006). Samples were then purified by streaking and were maintained on MRS slant at $4^{\circ} \mathrm{C}$.

\section{Physiological and biochemical tests}

All strains were initially tested for Gram reaction and catalase production activity 
(Harrigan, 1998; Aneja, 2006). Only Gram positive and catalase negative were further identified.

\section{Gas production from glucose}

In order to determine the homofermentative and heterofermentative characterization of isolates, $\mathrm{CO}_{2}$ production from glucose test was applied. Sugar tube with inverted Durham tubes were prepared and inoculated with $1 \%$ overnight fresh cultures. Then test tubes were incubated at $37{ }^{\circ} \mathrm{C}$ for $24 \mathrm{~h}$. After $24 \mathrm{~h}$ observed gas occurrence in Durham tubes for $\mathrm{CO}_{2}$ production from glucose.

\section{Sugar fermentation}

Three SS-1, SS-2 and SS-3 isolates were selected and subjected to sugar fermentation test. Fermentation of different sugars was studied in order to observe the growth of culture in Nutrient broth containing with $1 \%$ glucose, lactose, maltose, Fructose and mannitol individually.

\section{Ability of growth at different temperature and salt concentration}

Tolerance to different temperature and salt concentration was determined by growing the isolate in MRS broth at different temperature $10^{\circ} \mathrm{C}, 15^{\circ} \mathrm{C}, 37^{\circ} \mathrm{C}$ and $45^{\circ} \mathrm{C}$ and for salt tolerance MRS media supplemented with $1 \%, 2 \%, 3 \%, 4 \%, 5 \%, 6 \%, 7 \%, 8 \%$ and $9 \%$ of sodium chloride concentration. After $24 \mathrm{~h}$, the test cultures were observed for growth, indicated by turbidity in the medium.

\section{Probiotic properties of Isolates}

For the determination of probiotic properties of isolates these following major selection criteria were selected:

\section{Resistance to Low pH}

Being resistance to low $\mathrm{pH}$ is one of the major selection criteria for probiotics strain (Quwehand et al., 1999). Since, to reach the small intestine they have to pass through from the stressful conditions of stomach (Chou and Weimer, 1999). For acid tolerance selected strains were inoculated into MRS broth varying concentration of $\mathrm{pH}$ $(2,3,4,5,6$ and 8) and OD at $620 \mathrm{~nm}$ was taken after $24 \mathrm{~h}$ incubation at $37^{\circ} \mathrm{C}$ against the control ( $\mathrm{pH} 7.0)$.

\section{Tolerance against bile}

The Strains, resistant to low $\mathrm{pH}$, were screened for their ability to tolerate the bile salt. Although the bile concentration of the human gastro intestinal tract varies, the mean intestinal bile concentration is believed to be $0.3 \% \mathrm{w} / \mathrm{v}$ and the staying time is suggested to be 4h (Prasad et al., 1998). For bile tolerance of selected strains were inoculated into MRS broth varying concentration of bile salt $(0.05,0.10,0.15$, 0.30 and $0.50 \%$ ) and also MRS broth without bile salt as control and incubated at $37^{\circ} \mathrm{C}$ for $24 \mathrm{~h}$. Optical density (OD) of each culture was recorded at $620 \mathrm{~nm}$ after incubation.

\section{Antimicrobial activity}

The selected strains were examined according to their antimicrobial activity. For this purpose, strains were detected against the indicator organisms Escherichia coli (MTCC-1610), S.aureus (MTCC-1430), B.subtilis (MTCC-441) and P.vulgaris (MTCC-1771)

\section{Antibiotic sensitivity testing}

The antibiotic resistance of Lactobacillus species was assessed using different 
antibiotic discs on MHA plate seeded with the isolated strains. The antibiotics discs were placed on the surface of agar and the plates were kept at $4{ }^{\circ} \mathrm{C}$ for $1 \mathrm{~h}$ for diffusion and then incubated at $37{ }^{\circ} \mathrm{C}$ for $24 \mathrm{~h}$ (Halami et al., 1999). Zone of suppression of growth was assessed against the different antibiotic discs namely Amoxycillin $(10 \mu \mathrm{g})$, Cefaclor $(30 \mu \mathrm{g})$, Chloramphenicol $(30 \mu \mathrm{g})$, Neomycin $(30 \mu \mathrm{g})$, Doxycycline $(30 \mu \mathrm{g})$, Vancomycin $(30 \mu \mathrm{g})$, Furazolidone $(100 \mu \mathrm{g})$, Clarithromycine $(15 \mu \mathrm{g}), \quad$ Oxacillin $(1 \mu \mathrm{g})$, Clindamycin $(2 \mu \mathrm{g})$, Penicillin-G $(10 \mu \mathrm{g})$, Erythromycin $(15 \mu \mathrm{g})$

Diameter of inhibition zones were measured and results were expressed in terms of resistant(R), intermediate susceptibility (I), and suseptiblity (S) according to cut off levels proposed by Presscott et al.,(1999), NCCLS (2002).

\section{Results and Discussion}

There were different 77 isolates obtained using spread plate method from the curd and butter milk as a source. Further based on morphological, cultural and biochemical characteristics three isolates (SS-1, SS-2 and SS-3) were selected for probiotic study. These selected isolates were identified as bacilli and showed catalase test negative. None of the strains showed gas production. These indicate that all strains were homofermentative.

Further, effect of different salt concentrations and temperature on growth of isolates were studied. Results showed that selected three strains have good growth rate at the temperature $15^{\circ} \mathrm{C}, 37^{\circ} \mathrm{C}$ and $45^{\circ} \mathrm{C}$ (Table-1). All the selected three isolates were able to tolerate $1.0 \quad-6.0 \% \mathrm{NaCl}$ concentration (Table 1), however SS-3 was able to tolerate $\mathrm{NaCl}$ concentration even up to $9 \%$. Hoque et al., (2010) have also observed the $\mathrm{NaCl}$ (1-9\%) tolerance of Lactobacillus sp. isolated from yoghurts.

\section{Probiotic properties of Isolates}

It was found that the isolates could survive nearly at $\mathrm{pH} 3.0$ but all were inhibited at $\mathrm{pH}$ 2(Table-2, Figure 1). However amongst all isolates, SS-2 showed the highest resistance or tolerance at $\mathrm{pH} 3$. Similar observations are also made by Sieladie et al., (2011). According to results, all three isolates SS-1, SS-2 and SS-3 demonstrated good capacity to resist bile salts but SS-2 showed better resistance (Table 3, Figure 2). The gradual decrease in number of viable cells was observed when the concentration of bile salt was increased up to $1 \%$ (Klayraung et al., 2008). Lactobacillus isolates showed resistance at $0.3 \%(\mathrm{w} / \mathrm{v})$ bile salt were considered as bile resistance strains (Vinderola and Reinheimer, 2003).

The antimicrobial effects of all the isolates against selected pathogenic bacteria Escherichia coli, Staphylococcus aureus, Bacillus Subtilis, Proteus vulgaris were studied because they are occasionally found as food borne microorganisms that might cause gastroenteritis. The results are shown in Table 4. All three isolates showed the higher antibacterial potential to all test organisms however SS-2 shows highest potency to all test organisms which indicates that the cell free solution of isolated Lactobacillus species were able to inhibit the growth of all the test microorganisms. Garriga et al. (1998) have reported inhibition of one or more enteric indicator strains (E.coli, Salmonella enteritidis) by the Lactobacillus paracasei subsp. paracasei. However, Lactobacillus acidophilus strains isolated from infant faeces had weak antibacterial activity on E.coli and Yersinia enterocolitica (Xanthopoulous et al., 2000). Daeschel (1989) has reported that the 
antimicrobial effect of LAB is due to the production of lactic acid, reduction of $\mathrm{pH}$, acetic acid, diacetyl, fatty acids, aldehydes and other compounds.

The antibiotic susceptibility of all three isolates was assessed by disc diffusion method using MHA medium and the results are shown in the Table 5. All the isolates were sensitive to antibiotic cefaclor, chloramphenicol, Doxycycline. The isolate
SS-1 was resistant to Neomycin, Furazolidone, Erythromycin and the isolate SS-2 was resistance to Amoxycillin, Oxacillin, Clarithromycine while the isolate SS-3 was resistance to Neomycin, Furazolidone, Oxacillin and Penicillin - G. The antibiotic resistance traits among probiotic microorganisms are advantageous for survival in the gastrointestinal tract during antibiotic treatment.

Table.1 Characteristics of Lactic acid bacteria isolated Strains

\begin{tabular}{|c|c|c|c|}
\hline Characteristic & SS-1 & SS-2 & SS-3 \\
\hline Gram stain reaction & + & + & + \\
\hline Catalase reaction & - & - & - \\
\hline $\mathrm{CO}_{2}$ from glucose & - & - & - \\
\hline Indole test & - & - & - \\
\hline Methyl Red Test & - & - & - \\
\hline Vogues Proskauer Test & - & - & - \\
\hline Citrate Utilization test & - & - & - \\
\hline Urease test & - & - & - \\
\hline $\begin{array}{c}\text { Growth at } \\
15^{\circ} \mathrm{C} \\
37^{\circ} \mathrm{C} \\
45^{\circ} \mathrm{C}\end{array}$ & & $\begin{array}{l}+ \\
+ \\
+\end{array}$ & $\begin{array}{l}+ \\
+ \\
+\end{array}$ \\
\hline $\begin{array}{c}\text { Growth in medium } \\
1 \% \mathrm{NaCl} \\
2 \% \mathrm{NaCl} \\
3 \% \mathrm{NaCl} \\
4 \% \mathrm{NaCl} \\
5 \% \mathrm{NaCl} \\
6 \% \mathrm{NaCl} \\
7 \% \mathrm{NaCl} \\
8 \% \mathrm{NaCl} \\
9 \% \mathrm{NaCl}\end{array}$ & $\begin{array}{l}+ \\
+ \\
+ \\
+ \\
+ \\
+ \\
+ \\
- \\
-\end{array}$ & $\begin{array}{l}+ \\
+ \\
+ \\
+ \\
+ \\
+ \\
- \\
- \\
-\end{array}$ & $\begin{array}{l}+ \\
+ \\
+ \\
+ \\
+ \\
+ \\
+ \\
+ \\
+\end{array}$ \\
\hline $\begin{array}{c}\text { Sugar Fermentation } \\
\text { Lactose } \\
\text { Glucose } \\
\text { Mannitol } \\
\text { Fructose } \\
\text { Maltose }\end{array}$ & $\begin{array}{l}+ \\
+ \\
+ \\
+ \\
+\end{array}$ & $\begin{array}{l}+ \\
+ \\
+ \\
+ \\
+\end{array}$ & $\begin{array}{l}+ \\
+ \\
+ \\
+ \\
+\end{array}$ \\
\hline
\end{tabular}

*Positive Reaction (+), Negative Reaction (-) 
Table.2 Acid tolerance result-Absorbance at $620 \mathrm{~nm}$ by spectrophotometer

\begin{tabular}{|c|c|c|c|}
\hline $\mathbf{p H}$ & $\mathbf{S S - 1}$ & $\mathbf{S S - 2}$ & $\mathbf{S S - 3}$ \\
\hline $\mathbf{2}$ & 0 & 0 & 0 \\
\hline $\mathbf{3}$ & 0.191 & 0.251 & 0.101 \\
\hline $\mathbf{4}$ & 0.651 & 0.362 & 0.165 \\
\hline $\mathbf{5}$ & 1.17 & 0.565 & 0.577 \\
\hline $\mathbf{6}$ & 1.806 & 1.361 & 1.761 \\
\hline $\mathbf{8}$ & 0.162 & 0.114 & 0.5 \\
\hline
\end{tabular}

Table.3 Bile salt tolerance-Absorbance at $620 \mathrm{~nm}$ by spectrophotometer

\begin{tabular}{|c|c|c|c|}
\hline Bile salt Concentrations & SS-1 & SS-2 & SS-3 \\
\hline $\mathbf{0 . 0 5 \%}$ & 1.150 & 1.445 & 1.57 \\
\hline $\mathbf{0 . 1 0 \%}$ & 1.111 & 1.345 & 0.98 \\
\hline $\mathbf{0 . 1 5 \%}$ & 0.627 & 0.446 & 0.337 \\
\hline $\mathbf{0 . 3 0 \%}$ & 0.043 & 0.394 & 0.307 \\
\hline $\mathbf{0 . 5 0 \%}$ & 0.008 & 0.442 & 0.19 \\
\hline Without bile salt & 2.067 & 2.368 & 1.809 \\
\hline
\end{tabular}

Table.4 Antibacterial Activity

\begin{tabular}{|c|c|c|c|c|}
\hline Isolates & \multicolumn{4}{|c|}{ Diameter of inhibition zone (mm) } \\
\hline No & E.coli & S. aureus & B. subtilis & P. vulgaris \\
\hline SS-1 & 20 & 17 & 19 & 15 \\
\hline SS-2 & 25 & 30 & 20 & 32 \\
\hline SS-3 & 20 & 19 & 18 & 14 \\
\hline
\end{tabular}

Table.5 Lactic acid bacterial strains showing sensitivity/resistant with different antibiotics

\begin{tabular}{|c|c|c|c|c|c|c|c|c|c|c|c|c|}
\hline \multirow{2}{*}{ Isolates } & \multicolumn{10}{|c|}{ Antibiotics } & CX \\
\cline { 2 - 15 } & AX & CT & CH & $\begin{array}{c}\text { N } \\
\text { E }\end{array}$ & DX & ES & FX & SP & $\begin{array}{l}\text { O } \\
\text { C }\end{array}$ & ER & PG & CD \\
\hline SS-1 & S & S & S & R & S & S & R & I & S & R & I & S \\
\hline SS-2 & R & S & S & S & S & I & S & R & R & S & S & I \\
\hline SS-3 & S & S & S & R & S & M & R & S & R & S & R & S \\
\hline
\end{tabular}

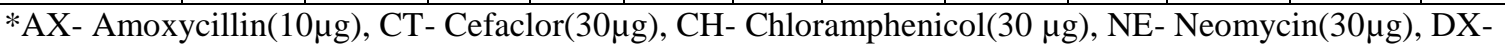

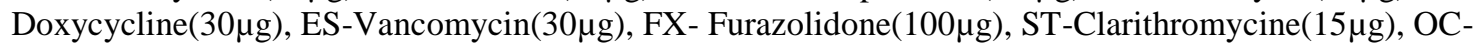

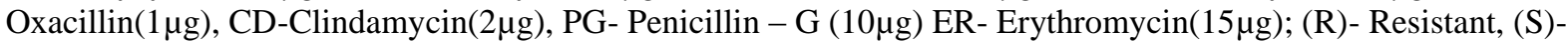

Sensitive, (I) Intermediatory according to the performance standards for antimicrobial disc (Pathetes Biological Laboratories.) suspension tests. 
Fig.1 Acid tolerance of Isolates

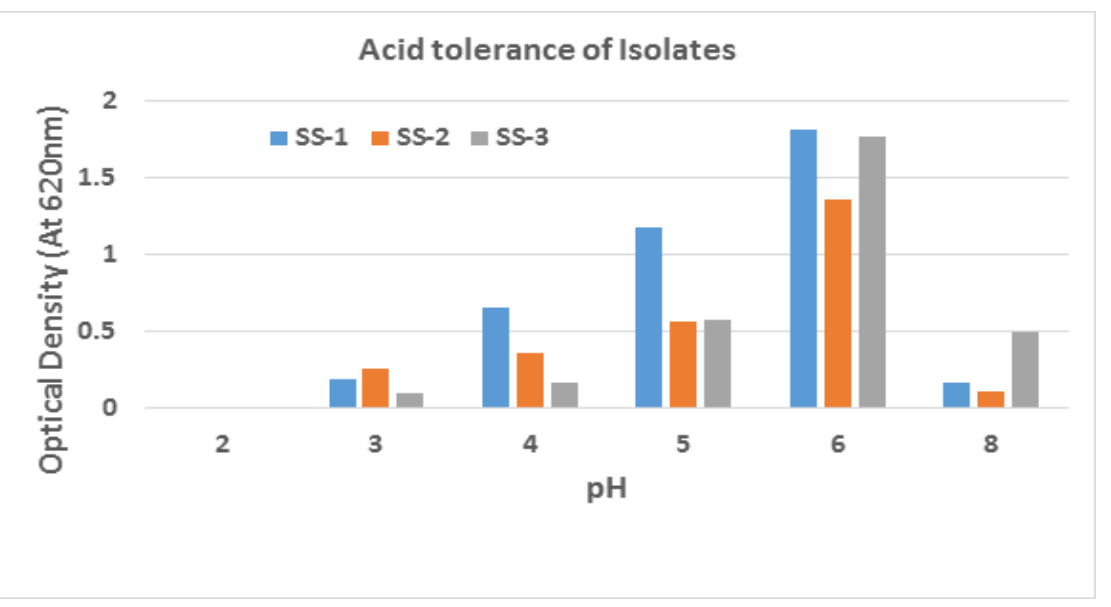

Fig.2 Bile Salt Tolerance

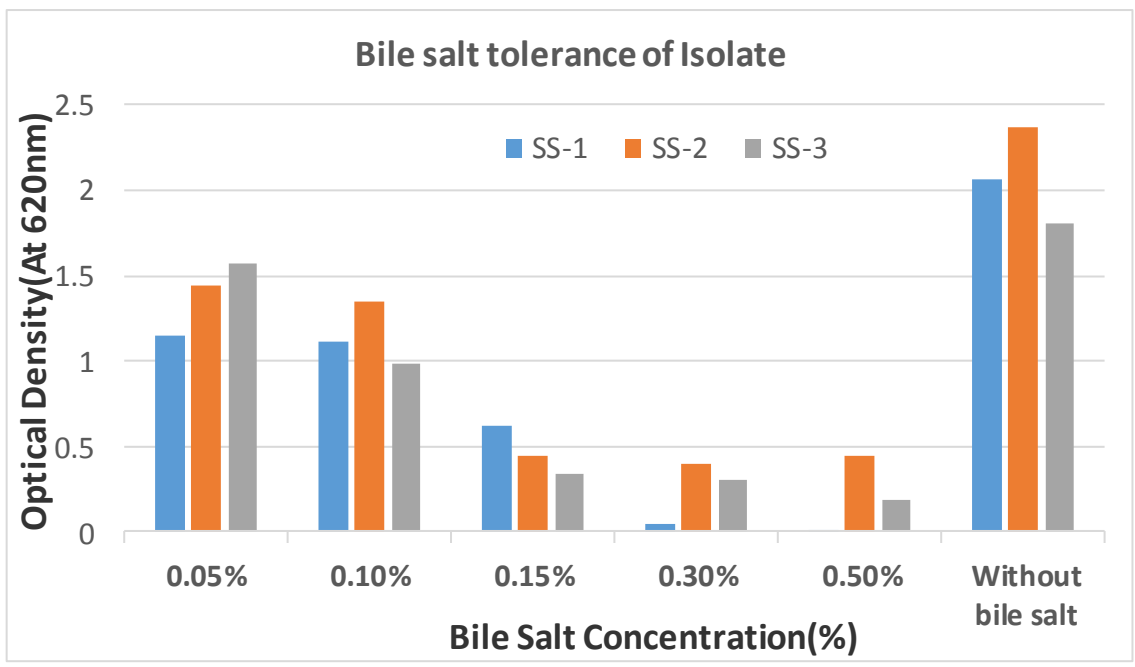

Such resistance to a wide spectrum of antibiotics indicated that if isolated probiotics induced in patients treated with antibiotic therapy may be helpful in faster recovery of the patients due to rapid establishment of desirable microbial flora. During co-administration of probiotics with antibiotics, probiotics should be resistant to certain antibiotics to survive in the gastrointestinal tract (Dixit et al., 2013). Resistance of the probiotic strains to some antibiotics could be used for both preventive and therapeutic purposes in controlling intestinal infections (EI-Naggar, 2004).
Results of antibiotic resistance/sensitivity of isolated strains are showing in Table -5 .

The present study results showed that the locally available dairy product Curd and buttermilk contain Lactobacilli which can tolerate inhibitory substances and were able to survive both in acidic and alkaline conditions. They exhibited antimicrobial activity against some indicator pathogens and were resistant to different antibiotics. Based on characteristics study of the isolates may have potential for natural preservatives and may also be considered for probiotic 
application or studies should be performed to use these isolates reliably for commercial applications.

\section{References}

Aneja, K.R. 2006. Experiments in Microbiology, Plant Pathology and Biotechnology. In: K.R. Aneja, editor. New Delhi: New Age International Publications, pp. 75-76.

Bauer, A.W., Kirby, W.M., Sherris, J.C. 1966. Am. J. Clinic. Path., 45, pp. 493496.

Çakir, I. 2003. Determination of some probiotic properties on Lactobacilli and Bifidobacteria. Ankara University Thesis of Ph.D.

Campbell-Platt, G. 1994. Fermented foods - a world perspective. Food Res. Int., 7(3), pp.253-257.

Chou, L.S. and Weimer, B. 1999. Isolation and characterization of acid-and biletolerant isolates from strains of Lactobacillus acidophilus. J. Dairy Sci., 82(1): pp.23-31.

Coeuret, V., Dubernet, S., Bernardeau, M., Gueguen, M. and Vernoux, J.P. 2003. Isolation, characterisation and identification of lactobacilli focusing mainly on cheeses and other dairy products. Le Lait, 83(4): pp.269-306.

Curragh, H.J. and Collins, M.A. 1992. High levels of spontaneous drug resistance in Lactobacillus. J. Appl. Bacteriol., 73(1), pp.31-36.

Daeschel, M.A. 1989. Antimicrobial substances from lactic acid bacteria for use as food preservatives. Food Technol.,(USA).

Dixit, G., Samarth, D., Tale, V. and Bhadekar, R. 2013. Comparative studies on potential probiotic characteristics of Lactobacillus acidophilus strains. Eurasia J. BioSci., 7, pp.1-9.

Farnworth, E.R. 2005. The beneficial health effects of fermented foods-potential probiotics around the world. $J$. Nutraceuticals, Functional \& Med. Foods, 4(3-4), pp.93-117.

Fuller, R. 1992. History and development of probiotics. In Probiotics (pp. 1-8). Springer Netherlands.

Garriga, M., Pascual, M., Monfort, J.M., Hugas, M. 1998. Selection of lactobacilli for chicken probiotic adjuncts. J. Appl. Microbiol., 84, pp.125-132.

Halami, P.M., Chandrashekar, A. and Joseph, R. 1999. Characterization of bacteriocinogenic strains of lactic acid bacteria in fowl and fish intestines and mushroom. Food Biotechnol., 13(2), pp.121-136.

Harrigan, W.F. 1998. Laboratory methods in food microbiology. Gulf Professional Publishing.

Holzapfel, W.H., Haberer, P., Geisen, R., Björkroth, J. and Schillinger, U., 2001. Taxonomy and important features of probiotic microorganisms in food and nutrition. The American J. Clinical Nutrition, 73(2), pp.365s-373s.

Hoque, M.Z., Akter, F., Hossain, K.M., Rahman, M.S.M., Billah, M.M. and Islam, K.M.D., 2010. Isolation, Identification and Analysis of Probiotic Properties of Lactobacillus Spp. From Selective Regional Yoghurts. World J. Dairy \& Food Sci., 5(1), pp. 39-46.

Kilara, A. 1982. Influence of in vitro gastric digestion on survival of some lactic cultures. Milchhwissenschaft, 37, pp. 129-132.

Klayraung, S., Viernstein, H., Sirithunyalug, J. and Okonogi, S. 2008. Probiotic properties of Lactobacilli isolated from Thai traditional food. Scientia Pharmaceutica, 76(3), pp.485.

Minamiyama, Y., Takemura, S., Yoshikawa, T. and Okada, S., 2003. Fermented grain products, production, properties and 
benefits to health. Pathophysiol., 9(4), pp.221-227.

NCCLS. 2002. Perfomance standards for antimicrobial disk susceptibility tests. Twelth information supplement. M100S12.

Oberg, C.J., Broadbent, J.R. and Mcmahon, D.J. 1998. Applications of EPS production by LAB .J. Applied Microbiol., 150, pp. 1187-1193.

Pelinescu, D.R., Sasarmaan, E., Chifiriuc M.C., Staca, I., Nohita, A.M., Avram, I., Serbancea, F. and Dimov, T.V., 2009. Isolation and identification of some Lactobacillus and Enterococcus by a polyphasic taxonomical approach. Romaniun Biotechnol. Letters, 14, pp.4225-4233.

Prasad, R.D.D., Reddy, M.R. and Reddy, G.V.N., 1998. Effect of feeding baled and stacked urea treated rice straw on the performance of crossbred cows. Animal feed science and technology, 73(3), pp.347-352.

Prescott, M.L., Harley, P.J., Klein, A.D., 1999. Antimicrobial chemotherapy. In microbiology forth edition. ISBN. USA. Pp. 678-695.

Quwehand, A.C., Kirjavainen, P.V., Shortt, C., Salminen, S. 1999. Probiotics: Mechanisms and established effects. Int. Dairy J., 9, pp. 43-52.

Rashid, M.H., Togo, K., Ueda, M., Miyamoto, T. 2007. Identification and characterization of dominant lactic acid bacteria isolated from traditional fermented milk Curd in Bangladesh. World J. Microbial. Biotechnol., 23(1), pp.125-133.
Savadogo, T.O., Ouattara, C.T.O.T., Bassole, I.H. and Traore, S.A. 2006. Bacteriocins and lactic acid bacteria. African J. Biotechnol., 5, pp. 678-683.

Sieladie, D.V., Zambou, N.F., Kaktcham, P.M., Cresci, A. and Fonteh, F. 2011. Probiotic properties of lactobacilli strains isolated from raw cow milk in the western highlands of Cameroon. Innovative Romanian Food Biotechnol., 9, pp.12.

Soliman, A.H.S., Sharoba, A.M., Bahlol, H.E.M., Soliman, A.S. and Radi, O.M.M. 2015. Evaluation of Lactobacillus acidophilus, Lactobacillus casei and Lactobacillus plantarum for probiotic characteristics. Middle East J. Appl. Sci., 5(1) pp. 94-101

Stiles, M.E. 1996. Biopreservation by lactic acid bacteria, Antone Van Leeuwenhoek, 70, pp.331-345.

Vinderola, C.G. and Reinheimer, J.A. 2003. Lactic acid starter and probiotic bacteria: a comparative "in vitro" study of probiotic characteristics and biological barrier resistance. Food Res. Int., 36(9), pp.895-904.

Walker, D.K. and Gilliland, S.E. 1983. Relationship among bile tolerance, bile salt deconjugation and assimilation of cholesterol by Lactobacillus acidophilus. J. Dairy Sci., 76, pp.956961.

Xanthopoulous, V., Litopoulou-Tzanetaki, E., Tzanetaki, N. 2000. Characterization of Lactobacillus isolates from infant faeces as dietary adjuncts. Food Microbiol., 17, pp. 205-215.

\section{How to cite this article:}

Patel, S.A., and Parikh, S.C. 2016. Isolation and Screening of Probiotic Potential Lactic Acid Bacteria from Local Dairy Products. Int.J.Curr.Microbiol.App.Sci. 5(11): 490-498. doi: http://dx.doi.org/10.20546/ijcmas.2016.511.057 